\title{
Analysis of ICG and The Size of Companies to Islamic Banking Financial Performance
}

\author{
Imelda Dian Rahmawati \\ Fakultas Ekonomi dan Bisnis, Universitas Airlangga \\ Surabaya, Indonesia \\ Fakultas Ekonomi dan Bisnis, Univesitas Muhammadiyah Sidoarjo \\ Sidoarjo, Indonesia \\ Imelda.dian.rahmawati-2016@feb.unair.ac.id
}

\author{
Bambang Tjahyadi \\ Universitas Airlangga \\ Surabaya, Indonesia \\ bambang.tjahjadi@feb.unair.ac.id
}

\begin{abstract}
The purpose of this research was to prove the application of Islamic Corporate Governance (ICG)and Firm Size effect on the financial performance of Islamic banking. This research includes the type of quantitative research using secondary data to test the hypothesis. The population that used a of 11 companies, and after the selection of 8 affected the company, which provided the sample. The results of this study ICG do not have an effect on the financial performance of Sharia banking. Because ICG is still included in the voluntary disclosure. The result demonstrated the significance of 0.625 value greater than 0.05 , and the size effect on the financial performance of the company Syaria Banking. Because of the size of the small company a great reflection of the companies that appear in the value of the total assets of the company at year end balance sheet. Then it is shown with the value significance of 0.021 less than 0.05 . The impact of this paper is sharia banking must have to give attention to ICG although in this paper haven't effect in company performance, because it can be differentiator with conventional bank
\end{abstract}

Keywords-Islamic corporate governance; company size; islamic banking

\section{INTRODUCTION}

The company's demands are now not only the return, but the company's concern on social values and the environment also becomes the center of attention of all stakeholders. In the current era, the demands of managing an entity with transparency is inevitable. One of them is a very broad form of transparency to the public is to implement good governance. The application of good governance is expected to increase oversight of the company towards the management to take a decision which effectively, to prevent the existence of the Act of cheating that are inconsistent with the objectives of the company are already agreed, it This can reduce the asymmetry of information between the parties

As for the underlying reasons for researching Islamic corporate governance (ICG) against Islamic banking financial performance was in line with the emergence of the event of bankruptcy. An Islamic financial institutions in the biggest Turkey in the year 2001. From financial and economic scholars of Islam is allegedly as a result of the weakness of the internal mechanism of the corporate governance and external. Issues about the weakness of corporate governance in Islamic banking industry is increasingly attracting the attention of the economic and financial experts to find solutions of islam. There are several factors that affect the performance of the company, among other managerial ownership [1] institutional ownership [2], and the size of the company [3]. Research on financial performance need to be done because it can reflect the success of a company in generating profits and remember the main goal of the company is to prosper our shareholders by continuing to multiply the wealth of the company. By knowing the factors that affect the financial performance, the company will be able to continue to improve and overcome the problems encountered so that survival (sustainability) can be maintained.

\section{THEORETICAL FRAMEWORK}

Agency Theory in the research that will discuss about Islamic corporate governance will also be using this theory because it has interconnected relationship to each other. In fact, each side between the agent and principal have the desire to maximize the benefits of its own profits than others.

Islamic accounting is not only as a form of accountability (accountability) against the management company owner (stakeholder), but also as accountability to stakeholders and Lord [4]. Enterprise Theory contains the values of Justice, truth, honesty, trust and accountability, forms the primary accountability to God Almighty.

Islamic corporate governance (ICG) is corporate governance based on the principles of Islam. Its operational principles and activities that are run should be based on moral and Islamic values, purpose of the ICG is the same as the conventional corporate governance, but in a moral code based on Islam (Bhatti, Bhatti and 2010). Islamic governance are factors corporate governance specifically by Islamic organizations. [5] say that the Islamic governance-oriented Islamic values as well as develop the reasonableness and fairness by considering the whole of the company's 
stakeholders. The Size of The Company is divided into three categories, namely, great company (large firm), intermediate (medium size), and small companies (small firm).

According to [6], the financial performance was an analysis conducted by a company to assess the extent to which a company has done with the use of the financial implementation of the rules properly. Such as creating financial statements that meet the standards and conditions in SAK (Financial accounting standards) or GAAP (General Accepted Accounting Principle) and other.

Islamic corporate governance is Islamic corporate governance corporate governance is based on the principles of islam. Principle and operational activities that are run should be based on moral and Islamic values, the goal is the same as the conventional corporate governance, but in a moral code based religion of islam. It is done to be able to provide benefits to the bank and its stakeholders. Financial performance was an analysis conducted by a company to assess the extent to which a company has done with the use of the financial implementation of the rules properly.

A. The Relationship of The Size of The Company with The Financial Performance of Islamic Banking

Certain measurements required to analyze the financial performance of a company. The company's performance can be assessed through two aspects, namely the financial aspects and aspects of non financial. The financial aspects of the assessment can be done by analyzing the financial statements drawn up by the management. Success in achieving the objectives of the company is the achievement of management. Assessment of achievement or performance of a company is measured because it can be used as a basis for decision making both internal and external parties. Corporate governance is a system of regulating and controlling the companies that are expected to provide and enhance the company's value to shareholders. Thus, the application of islamic corporate governance can enhance the value of trusted companies. [7], [16] suggests that corporate governance is effective in the long run could increase the financial performance of the company and benefit its shareholders.

H1: Islamic corporate governance financial performance effect on Islamic banking

The size of the companies is a reflection of how large scale operations are run by a company that is reflected in the value of the total assets of the company at year end balance sheet [8]. With respect to total assets, if the company has reached a stage of maturity (maturity) or well established.

H2: the size of the company's financial performance affects Islamic banking

Application of islamic corporate governance can enhance the value of trusted companies. [7], suggests that corporate governance is effective in the long run could increase the financial performance of the company and benefit its shareholders.

H3: Islamic corporate governance and firm size effect on the financial performance of Islamic banking

\section{METHODS}

Research methods used in this research is quantitative research methods by using secondary data as a data source [17]. In this research, secondary data used is the annual Islamic banking which is listed on the Indonesia stock exchange in the period 2012-2015. Free variables (X) in this research is Islamic Corporate Governance (ICG) based on research (Surdayanti and Eskadewi, 2012) how to calculate score Islamic governance is as follows:

\section{IG-Score $=$ DPS + NUM + PHD + MRISK}

Description:

DPS

NUM

PHD $\quad \begin{aligned} & \text { Islamic Bank } \\ & \text { : educational qualifications DPS }\end{aligned}$

MRISK : risk management in Islamic banks

Measurements in this indicator is to look at the existence of the DPS in the Islamic bank. Measurements in this indicator follows previous research conducted by the [9] ) when Islamic banks have a DPS will be assigned a score of 1 , if Islamic banks don't have DPS then was given a score of 0 . Measurements in this indicator is to calculate how much a member of the Shariah Board of Trustees in an Islamic banking. Measurements in this indicator follows previous research conducted by the [9]. When the number of members of the DPS owned Islamic banks as much as 3 or more in the give 1 , if the number of members of the DPS owned Islamic bank under 3 and given a score of 0 . Educational

- Qualifications Of Sharia Supervisory Board

Measurements in this indicator is to look at whether there is a Shariah Supervisory Board members who have a good level of education or not. [10] says that Sharia watchdogs are required to have a degree of doctor of education (S3). The measurement of this indicator follows previous research that has been done by [9]namely when there are one or more members of the Shariah Supervisory Council at least educated doctor (S3) then it will be assigned a score of 1 and if there are no It will be given a score of 0 .

- Risk Management In The Islamic Bank (X1)

Measurements in this indicator is to look at whether Islamic banks have risk management. When Islamic banks have risk management will be assigned a score of 1 , but if Islamic banks don't have risk management then akandiberi score 0 .

- Size of Company (X 2)

The size of the company shows the value of the assets owned by the company. If a company has more assets than other similar companies, then this indicates that the company is not only bigger than other companies.

One of the milestones that show the small size of the company is a great company. Determination of size of company can be expressed with total sales, total assets, the average level of sales and the average level of assets 
[11]. The size of the company are measured using the $\log$ naturan total asset.

Company size $=\log (n)$ (Total assets)

- $\quad$ A Bound Variable (Y)

According to [12], the financial performance of banking is a picture to which the level of success achieved by the bank in operaionalnya activities. In this study, financial banking performance is measured using the Return On Asset (ROA).

The population in this study i.e. the whole Islamic banks which are in Indonesia totalling eleven (11) unit of the bank. The selection of the sample in this research will be conducted with the purposive sampling technique, i.e. only eligible data/criteria that will be used as samples.These criteria i.e. Islamic banks listed in bank Indonesia are published yearly and annual report annual report during the period of 20122015 which can be accessed from the Indonesia stock exchange or with the website (www.idx.co.id <http: www.idx.co.id="">). Sample Criteria No. 1 number of Islamic banks were listed on the Indonesia stock exchange (idx) 112 Islamic banks which do not correspond to the criteria (2) 3 Total Islamic bank 9 Total sample (sum of bank syariah $\mathrm{x}$ four-year) Data Source: 36 Processed, 2017. Based on the above criteria, then the obtained nine (9) units of Islamic banks. $</$ http: $>$ Because there is one Islamic bank which does not publish annual report i.e. MAYBANK in 2014. Islamic banks are not issuing financial statements i.e. MAYBANK in 2013, and the BVIS in 2012-2013. Techniques of Data analysis and Hypothesis testing of the samples used in this study is selected by purposive sampling, namely sample selected based on certain criteria. This research uses techniques of quantitative analysis. Existing sample population in accordance with the research objectives, sample taken from the years of 2012-2015. The data in this study will be processed and analyzed with the tools of analysis as follows:

- The Descriptive Statistical Analysis

Descriptive statistical analysis related to data collection, data compaction, sampling and presentation of the results of the compaction.

\section{TABLE I. DESCRIPTIVE STATISTICS}

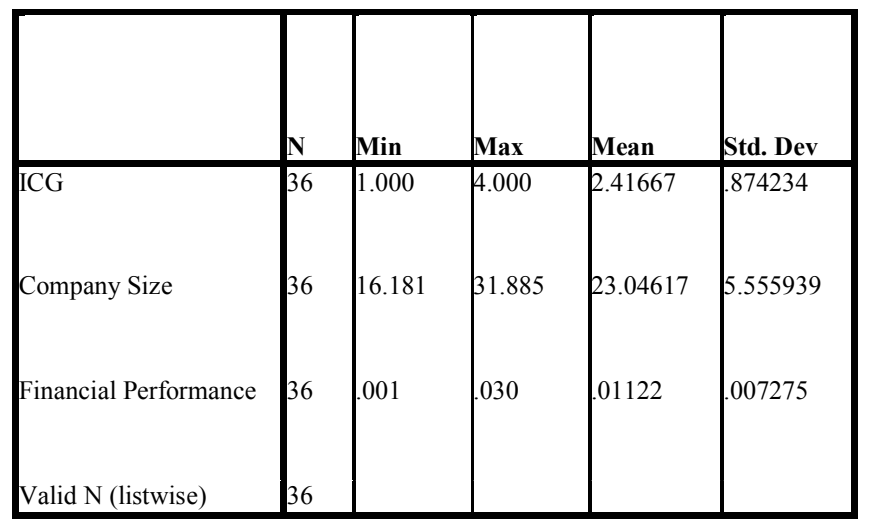

Descriptive statistics are used to describe statistically the variables in the study. Descriptive statistics will give an overview of the research variables in general, that is about the average (mean), and the size of the dispense system that is standard deviation, maximum value, and the minimum value.

- Normality Test

Based on the graph of a Normal P-Plot in the figure above indicates that the regression model in this study deserves to wear, because on a Normal P-graph Plot above seen that the points spread around the diagonal lines so as to meet the assumptions of normality.

- Multikolinearity

Based on the table above States that the value of Tolerance to each independent variable $>0.1$ and 10 so that $\mathrm{VIF}<$ inferred that the equations of the regression model is a regression equation which is good because having no multicollinearity.

- Heteroskedastisitas Based on the picture above States that the data are spread randomly, then it can be inferred that heteroskedastisitas does not occur.

- Multiple Regression Analysis Multiple regression models (multiple regression) analysis is a tool used in this research. Multiple linear regression analysis was used to measure the influence of more than one variable against the free variable is bound.

$$
\begin{array}{ll}
\mathrm{Y} & =\alpha+\beta \mathrm{X} 1+\beta \mathrm{X} 2+\mathrm{e} \\
\mathrm{Y} & =0.022+0.002 \mathrm{X} 1-0.001 \mathrm{X} 2+\mathrm{e}
\end{array}
$$

Description:

$$
\begin{array}{ll}
\mathrm{Y} & =\text { the performance of Islamic Banking Finance } \alpha= \\
& \text { Constant } \\
\beta & =\text { Regression Coefficient } \\
\mathrm{X} 1 & =\text { Islamic Corporate Governance (ICG) } \\
\mathrm{X} 2 & =\text { The Size Of The Company } \\
\mathrm{e} & =\text { error }
\end{array}
$$

Constant value of 0.022 stated that no two free variables, are considered equal to zero then the financial performance of Islamic banking will remain constant. The value of the coefficient of 0.002 stated that variable Islamic corporate governance, financial performance against Islamic banking is positive and strong enough, if islamic corporate governance financial performance then increased Islamic banking will be increasing. The value of the coefficient of 0.001 -States that the variable size of the company's financial performance against Islamic banking is negative. And is not strong enough, if the size of the company declined then the performance of Islamic banking will progressively decrease.

- The Test of Hypothesis

Hypothesis testing is a procedure done with tujuanmemutuskan whether accept or reject hypotheses about population parameters. 
- $\quad$ Test the Persial (T test)

Based on the results of the test $t$ done, on islamic corporate governance variables retrieved the value significance of $0.336>0.05$ then $\mathrm{H} 1$ is not accepted. So that it can be interpreted that the islamic corporate governance variables have no effect against variables bound to financial performance. Based on the results of the test $\mathrm{t}$ done, on a variable size company obtained the value of 0.030 significance 0.05 then $\mathrm{H} 2$ $<$ accepted. So that means that the size of the variable variable bound to the company's financial performance.

Based on the table above can be described simultaneously hypothesis test (test F) as follows, with $\mathrm{df} 1=\mathrm{k}$ $=2$ and $\mathrm{df} 2=\mathrm{n}-\mathrm{k}-1=36-2-1=33$, thus obtained ftabel $(0.05$; 33) amounted to 3.28. The value fhitung obtained from pengelolahan SPSS results presented in the table above, so that in accordance with the results of the calculation of the test F, retrieved the value of the fhitung of 2.842. So the value of fhitung is less than ftabel on IE 3.28. Significant value obtained is amounting to 0.073 , so this significant value smaller than 0.05 . Because fhitung $<\mathrm{ftabel}=2.842<3.28$ and sig $>0.05=0.073>0.05$. Therefore H0 is accepted and Ha was rejected, meaning islamic corporate governance variables (X 1) and size of company (X 2) simultaneously does not have an effect on the dependent variable i.e. financial performance of Islamic banking (Y).

\section{DISCUSSION}

\section{Islamic Corporate Governance Financial Performance Effect on Islamic Banking}

The results showed islamic corporate governance does not have an effect on the financial performance of Sharia banking. Islamic corporate governance are all factors corporate governance specifically by business organizations. A staple of islamic corporate governance is the Sharia Supervisory Board (DPS) and the internal controls in it. Sharia Supervisory Board is the Board that is in charge of giving advice and suggestions to the Board of Directors and oversee the activities of the Bank in order to comply with Sharia principles.

Based on the results of the t-test showed that the ananlisis variable islmaic corporate governance as measured using the IG-Score consisting of the existence of a number of members of the DPS, DPS, DPS, educational qualifications and risk management thitung has a value of the significance and value of 0.9770 .336 . The value significance of 0.336 greater than 0.05 and the value of 1.68830 ttabel thitung $<$ so the first hypothesis is not accepted meaning that islamic corporate governance does not affect the performance of the kuangan Islamic banking.

Disclosure of information in the annual report can be divided into two, namely mandatory disclosure (mandatory disclosure) and voluntary disclosure (voluntary disclosure). [13] describes the mandatory disclosure is a disclosure that should be raised in the annual report according to bapepam. While the voluntary disclosure disclosure is no disclosure as required by bapepam, in other words the excess of disclosure required. Voluntary disclosure is the business data analysis, management of business data, forward looking information, company background, information about management and shareholders. Disclosure-disclosure is no standard requiring to publish all of the complete annual report in each bank. When a company gives a compulsory and a voluntary disclosure is at once, meaning that company provide full disclosure (full disclosure). If the company provides the complete information, then the company's ever-increasing levels of concern. Therefore the management of fear caused free riding, where there are certain parties that will harness the potential for information purposes. Then each company define the limitations of the information would be released to the researchers and investors. Based on the results of this research it is known that islamic corporate governance variables have no effect on the financial performance.

\section{Influence of Size of Company Financial Performance Against Islamic Banking}

The results showed the size of the company's effect on the financial performance of Sharia banking. The size of the company said that the larger the size of the company information available to investors in decision-making related to investments in the company's stock more and more. Based on the results of the t-test showed that the ananlisis variable is the size of a company is measured using the $\log (\mathrm{n})=$ total asset, $t$ account has a value of-2.268 and value the significance of 0.030 . The value of 0.030 significance smaller than 0.05 and the value of $1.68830 \mathrm{t}$ table $<\mathrm{t}$ account so the second hypothesis is accepted which means that the size of the company's effect on the performance of the kuangan Islamic banking.

The size of the company the company's inability to get low yields high financial performance on certain sales levels. This is a reflection of the great small company that appears in the value of the total assets on the balance sheet of the company late last year, as measured using the tranformasi natural logarithm of total assets. The size of the company shows the activity of the company owned. Based on the results of the research note that the company has the size of a variable impact on financial performance. This does not support the research conducted by [14] saying that the company's size has no effect on the financial performance, with this from research in the past does not equal research now. However, in contrast to the results of research conducted by [15], saying that the company's size has an impact on financial performance, previous research by this same with research. The influence of Islamic Corporate Governance and the size of the company's financial Performance Against Islamic banking results showed islamic corporate governance and the size of the company doesn't have an effect on the financial performance of Sharia banking. Islamic corporate governance are all factors corporate governance specifically by Islamic business organizations, and the size of the company said that the larger the size of the company information available to investors in decision- 
making related to investments in the company's stock more and more.

3. Islamic Corporate Governance and Firm Size Effect on the Financial Performance of Islamic Banking

Based on the results of the test analisis $f$ indicates that the variable islamic corporate governance and firm size has a value smaller than $f$ account, $f$ table i.e. 3.28. Significant value obtained is amounting to 0.073 , so this significant value smaller than 0.05 . Because f account $<\mathrm{f}$ table $=2.842<3.28$ and $\operatorname{sig}>0.05=0.073>0.05$. Therefore H0 is accepted and $\mathrm{Ha}$ was rejected, meaning islamic corporate governance variables (X 1) and size of company (X 2) simultaneously does not have an effect on the dependent variable i.e. financial performance of Islamic banking (Y). So the third hypothesis has no effect. Therefore islamic corporate governance including the valountary disclosure means disclosure of information annual report that not everything is published. There are certain limitations of his company. Thus the investors still monitor and consider to infuse capital in the company. And the size of the company the company's inability to get low yields high financial performance on certain sales levels. This is a reflection of the great small company that appears in the value of the total assets of the company at year end balance sheet. Based on the results of this research note that variables islamic corporate governance and firm size has no effect on the performance of finance.

\section{CONCLUSION}

Islamic corporate governance does not have an effect on the financial performance of banking Sharia, so that the first hypothesis in this study was not accepted. Disclosure of information in the annual report Islamic corporate governance included in the disclosure is voluntary disclosure (voluntary disclosure), as the company is not obliged to publish information of the complete annual report in every bank and there is no standard which obliged.

Size effect on company financial performance of Islamic banking, so that the second hypothesis in this study was received. The size of the company the company's inability to get low yields high financial performance on sales level certain. Finally, Islamic corporate governance and firm size has no effect on performance of finance Islamic banking, so the third hypothesis in this study was not accepted. There are certain limitations of the company. Thus the investors still monitor and consider to infuse capital in the company.

\section{ACKNOWLEDGEMENT}

Thanks to Universitas Airlangga Surabaya and Universitas Muhammadiyah Sidoarjo for supporting this research.

\section{REFERENCES}

[1] Mudambi, Ram dan Carmela Nicosia. Ownership Structure and Firm Perfomance. 1995

[2] Kartikawati, Wening. Pengaruh Kepemilikan Institusional Terhadap Kinerja Keuangan Perusahaan. 2007

[3] Sembiring, Seniwati. Pengaruh Ukuran Perusahaan Dan Kebijakan Pendanaan Terhadap Kinerjakeuangan Pada Perusahaan Bisnis Properti
Di Bursa Efek Jakarta. Universitas Sumatra Utara, Medan. 2008.

[4] Triyuwono, Iwan. Akuntansi Syariah Perspektif, Metodologi dan Teori. Jakarta : Raja Grafindo Persada. 2012.

[5] Lewis. Islamic Corporate Governance. review of islamic economic vol. 9:Pp. 5-29. 2005.

[6] Fahmi, Irham. Analisis Laporan Keuangan.Cetakan Ke-2. Bandung: Alfabeta

[7] Report on corporate governance. Five Year to the dey. Institute of corporate directors. Toronto Stock Exchange. 1999.

[8] Sujoko dan Ugy Soebiantoro.. Pengaruh struktur Kepemilikan Saham, Leverage, Faktor Interen dan Faktor Eksteren terhadap Nilai Perusahan. Jurnal Manajemen dan Kewirausahaan. Vol 9,No. 1. 2007.

[9] Surdayanti, Dwi dan Yunita Eskadewi. Pengaruh Corporate Governance Terhadap Tingkat Pengungkapan Corporate Social Responsibility Di Bank Syariah. Jurnal Ekonomi Dan Bisnis. 2012

[10] Farook, S. M. K. Hassan dan R Lanis. Determinants Of Corporate Social Accounting And Responsibility Gdisclosure: The Case Of Islamic Banks. Journal Of Islamic Business Research. 2011.

[11] Melinda, Fong Ida dan Sutejo Bertha Silvia. Interpendensi Kepemilikan Manajerial dan Kepemilikan Institusional Terhadap Kinerja Keuangan. Manajemen dan Bisnis vol. 7 no. 2. 2008

[12] Harahap, Sofyan Syafri, Analisis Kritis Atas Laporan Keuangan, Cetakan Kesebelas, Penerbit Rajawali Pers, Jakarta. 2013

[13] Grais dan Pellegrini. Corporate Governance and Stakeholders' Financial Interests in Institutions Offering Islamic Financial Services.Wold Bank Policy Research Working Paper 4052. November, 2006.

[14] Ardianingsih dan Ardiyani. Analisis Pengaruh Struktur Kepemilikan Terhadap Kinerja Perusahaan. Jurnal Pena vol. 19 No. 2. 2010.

[15] Elfianto Nugroho. Analisis pengaruh likuiditas, pertumbuhan enjualan, perputaran modal kerja, ukuran perusahaan dan leverage terhadap profitabilitas perusahaan. Undip.2011

[16] Bhatti dan Bhatti. Toward Understanding Islamic Corporate Governance Issues In Islamic Finance. Asian Politics and Policy Vol. 2, No. 2:Pp 25-38. 2010.

[17] Sugiyono. Metode Penelitian Bisnis (Pendekatan Kuantitatif, Kualitatif, dan R \& D). Bandung: Alfabeta. 2010. 